\title{
Formation of democratic values and competence among medical students at the ambushes of the interdisciplinary integration (Sovietization history of Ternopil region in the 1940s)
}

\author{
Kravchuk L. V., Kadobnyi T. B., Kravchuk L. 0. \\ I.Ya. Horbachevsky Ternopil National Medical University, Ternopil, Ukraine
}

Received: 10.11 .2020

Accepted: 22.12 .2020

\begin{abstract}
The article reveals the inhumane nature of the communist system, the inefficiency of command-andcontrol Soviet methods of managing agriculture and industry. The activity of the Soviet power is analyzed, which from September 1939-1941 began to implement force management methods. This issue is especially relevant today, when Ukrainian society solves a set of political, economic and socio-cultural problems generated in the previous historical period by authoritarian forcible replacement of a democratic socialist state, market economy administrative-planned, universal values - values of communist ideology. In the main part of the article the author, using the achievements of domestic and foreign historical science, the source base of national and foreign archives, applying the theoretical and methodological experience of the past and innovations of the present, managed to expand unbiased, comprehensive, multi-vector and diverse study of socio-political and socio-economic western Ukrainian lands at the initial stage of forceful accession to the USSR as part of the USSR. Modern analysis and coverage of socio-political and socio-economic transformations in Ternopil region in September 1939-1941 contributes to the establishment of narrative, de-Sovietization of consciousness of certain segments of modern society and awareness of the aggressive nature of totalitarianism. Secondly, the Sovietization of Ternopil took place simultaneously with the liquidation of Poland by destroying democratic European values, with the rigid imposition of Stalin's party-state policy aimed at establishing an authoritarian administrative-command system of government in the western Ukrainian region. The main features of Sovietization, the author identifies, are: the use of military force at the initial stage of its implementation; formation of administrative-command management system; authoritarian interference of party bodies in all spheres of life in the region; nationalization of industry and collectivization of agriculture, etc. State-owned enterprises, as well as enterprises of the socialized municipal economy, were formed on the basis of nationalized industrial, financial, trade and communal facilities. The practical significance of the results of LV Kravchuk's research is that its main provisions, theoretical generalizations and conclusions can be used in the process of further, more detailed study of such individual industries as industry, agriculture in the field of local lore and in preparing special courses in History. Ukraine of the twentieth century. The struggle against the communist system continued in the 1970s and 1980s, and the creation of the Ukrainian People's Movement and other political and public organizations accelerated the collapse of the Soviet empire in 1991. Therefore, in the proposed articles, the main scientific provisions are professionally justified, are of considerable scientific interest. The factual material is systematized and consistently presented, the conclusions are clear and understandable.
\end{abstract}

Key words: Communism, nationalization, Soviet power, peasant, agriculture, private property, industry, planning, accounting.

\section{Формування демократичних цінностей та компетентності у студентів- медиків на засадах міждисциплінарної інтеграції ( історії радянізації Тернопільщини в 40-х роках)}

\author{
Кравчук Л. В., Кадобний Т. Б., Кравчук Л. О. \\ Тернопільський національний медичний університет імені І. Я. Горбачевського, Тернопіль, Україна
}

Анотація. В статті розкрито антигуманну природу комуністичної системи, неефективність командноадміністративних радянських методів управління сільським господарством, промисловістю. Проаналізовано

\footnotetext{
Corresponding Author: Kravchuk Leonid Vasylovych. Phone: 0985597507. E-mail: kravchuklv@tdmu.edu.ua I.Ya. Horbachevsky Ternopil National Medical University, Vul. Berezova, 11/31, Ternopil, Ukraine.

Відповідальний автор: Кравчук Леонід Васильович. Тел. 0985597507. E-mail: kravchuklv@tdmu.edu.ua Тернопільський національний медичний університет ім. І. Я. Горбачевського. вул. Березова 11/31, м. Тернопіль, Україна.
} 
діяльність радянської влади яка з вересня 1939-1941рр., почала впроваджувати силові методами управління. Ця проблематика $€$ особливо актуальною на сьогодні, коли українське суспільство вирішує комплекс політичних, економічних і соціально-культурних проблем, породжених у попередній історичний період авторитарною насильницькою заміною демократичної держави соціалістичною, ринкової економіки адміністративно-плановою, загальнолюдських цінностей - цінностями комуністичної ідеології. В основні частині статті автор, використовуючи надбання вітчизняної та зарубіжної історичної науки, джерельну базу національних і зарубіжних архівів, застосовуючи теоретико-методологічний досвід минулого та інновації сьогодення, спромігся розширити неупереджене, комплексне, багатовекторне й різнопланове вивчення суспільно-політичних та соціально-економічних перетворень на західноукраїнських землях на початковому етапі силового приєднання до УРСР в складі СРСР. Сучасний аналіз та висвітлення суспільно-політичних та соціально-економічних трансформацій на Тернопільщині у вересні 1939-1941 рр. сприяє утвердженню наративу, дерадянізації свідомості певних верств сучасного суспільства та усвідомлення агресивної природи тоталітаризму. По-друге, радянізація Тернопілля проходила одночасно 3 ліквідацією Польщі шляхом знищення демократичних європейських цінностей, з жорстким насадженням сталінської партійно-державної політики, спрямованої на утвердження в західноукраїнському регіоні авторитарної адміністративно-командної системи управління, рудименти якої реально відчутні в сучасному українському соціумі. Основні ознаки радянізації автор виділяє, це: застосування військової сили на початковому етапі її здійснення; формування адміністративно-командної системи управління; авторитарне втручання компартійних органів у всі сфери життя регіону; націоналізація промисловості та колективізація сільського господарства;, тощо. На базі націоналізованих промислових, фінансових, торговельних і комунально-побутових об'єктів формувалися державні підприємства, а також підприємства усуспільненого міського господарства. Практичне значення результатів дослідження Л.В.Кравчука полягає у тому, що його основні положення, теоретичні узагальнення та висновки можна використати в процесі подальшого, детальнішого дослідження таких окремих галузей як промисловість, сільське господарство в масштабах краєзнавчого плану так і при підготовці спеціальних курсів з Історії України XX ст. Боротьба проти комуністичної системи продовжувалася у 70-80-х роках, а саме створення Українського Народного руху та інших політичних і громадських організацій прискорили розвал радянської імперії у 1991 р. Отже в запропоновані статті основні наукові положення $€$ фахово обгрунтованими, становлять значний науковий інтерес. Фактичний матеріал систематизовано і послідовно викладено, висновки чіткі і зрозумілі.

Ключові слова: Комунізм, націоналізація, радянська влада, селянин, сільське господартво, приватна власність, промисловість, планування, облік.

\title{
Формирование демократических ценностей и компетентности студентов-медиков на основе междисциплинарной интеграции (истории советизации Тернопольщины в 40-х годах)
}

\author{
Кравчук Л. В., Кадобний Т. Б., Кравчук Л. 0. \\ Название организации, Город, Страна
}

\begin{abstract}
Аннотация. В статье раскрыто антигуманной природе коммунистической системы, неэффективность командно-административных советских методов управления сельским хозяйством, промышленностью. Проанализирована деятельность советской власти которая с сентября 1939-1941гг., Начала внедрять методы управления. Эта проблематика особенно актуальна сегодня, когда украинское общество решает комплекс политических, экономических и социально-культурных проблем, порожденных в предыдущий исторический период авторитарной насильственной заменой демократического государства социалистической, рыночной экономики - административно-плановой, общечеловеческих ценностей - ценностями коммунистической идеологии. В основные части статьи автор, используя достижения отечественной и зарубежной исторической науки, родниковую базу национальных и зарубежных архивов, применяя теоретико-методологический опыт и инновации настоящее, постарался расширить беспристрастное, комплексное, многовекторное и разноплановое изучение общественно-политических и социально-экономических преобразований на западноукраинских землях на начальном этапе силового присоединения к УССР в составе СССР. Современный анализ и освещение общественно-политических и социально-экономических трансформаций в Тернопольской области в сентябре 1939-1941 гг. Способствует утверждению нарратива, десоветизации сознания определенных слоев современного общества и осознание агрессивной природы тоталитаризма. Вовторых, советизация Тернопольщины проходила одновременно с ликвидацией Польши путем уничтожения демократических европейских ценностей, с жестким насаждением сталинской партийно-государственной политики, направленной на утверждение в западно регионе авторитарной административно-командной системы управления, рудименты которой реально ощутимы в современном украинском социуме. Основные признаки советизации автор выделяет, это: применение военной силы на начальном этапе ее осуществления; формирование административно-командной системы управления; авторитарное
\end{abstract}


вмешательство компартийных органов во все сферы жизни региона; национализация промышленности и коллективизация сельского хозяйства. На базе национализированных промышленных, финансовых, торговых и коммунально-бытовых объектов формировались государственные предприятия, а также предприятия обобществленного городского хозяйства. Практическое значение результатов исследования Л. В. Кравчука заключается в том, что его основные положения, теоретические обобщения и выводы можно использовать в процессе дальнейшего, более детального исследования таких отдельных отраслей как промышленность, сельское хозяйство в масштабах краеведческого плана так и при подготовке специальных курсов по истории Украина XX века. Борьба против коммунистической системы продолжалась в 70-80-х годах, а именно создание Украинского Народного движения и других политических и общественных организаций ускорили развал советской империи в 1991. Так что в предложенные статьи основные научные положения является профессионально обоснованными, представляют значительный научный интерес. Фактический материал систематизирован и последовательно изложено, выводы четкие и понятные.

Ключевые слова: Коммунизм, национализация, советская власть, крестьянин, сельское господартво, частная собственность, промышленность, планирование, учет.

\section{Bcmyn}

Вивчаючи на першому курсі предмети суспільного циклу( історія України , т.3. та фрілософрія т.4.) , студенти мають можливість більш глибше і комплексніше ознайомитись з передумовами виникнення , розвитку та поширення соціалістичних ідеалів рівності, братерства та інше, а також з авторами та прихильниками платформи комунізму. Основним завданням в роботі з студентством, $\epsilon$ аналіз об`єктивного та компетентного розуміння комуністичних ілюзій що зародились як фрілософські теорії в багатих країнах Європи, а впроваджувались в реальне життя у найбідніші країні - СРСР. Тому використовуючи інформативний метод, перед студентами необхідно розкрити справжню природу марксистсько-ленінської концепції.

Комунізм - означає спільність (тих чи інших матеріальних цінностей), власності.

Звідси, як система, комунізм є вченням про поглинання приватного інтересу і перетворення його в інтерес колективний.

Комуністична ідеологія не визнає приватну власність, а сповідує рівноправність, тобто рівноправну участь у власності ближнього, без роздумів, чи бажає твій ближній цього чи ні.

Комуністична теорія має в свої основі на перший погляд гуманні ідеї, а своєю метою - втілення цих ідей в життя, а саме: на основі рівноправності всього суспільства влаштовує рівноправне користування всім, що складає необхідність, зручності і задоволення в людському житті і по можливості покращити становище всіх людей, та дати можливість рівномірному розвитку всім іншим особам. Отже, комунізм породжується із співчуття до бідувань і страждань людей, що походять від бідності, приховуючи справжньою свою природу, яка спроможна існувати тільки на бідності.

Основним ґрунтом на якому приживається і розростається комунізм є найбідніші верстви населення, або класи, і лідером тут виступає пролетаріат, який не тільки із заздрістю поглядає на власників ,але за вказівкою партії готовий прийняти най активнішу участь в боротьбі за матеріальні блага.

В основі всієї комуністичної системи лежить тільки розрахунок. Віднімаючи власність в одних і передаючи її іншим, комунізм суперечить почуттю справедливості і порушуючи і знищуючи права інших, одночасно опирається на власне право. Представивши цілісну картину що собою представляє комунізм ,необхідно розкрити передумови його проникнення на територію Західної України та наслідки цієї системи для місцевого населення яке жило за іншими цінностями до вересня 1939p. Переконливо про політику комуністичної системи говорять події на передодні радянсько-німецького зіткнення на території Західної України.

Теоретико-концептуальними засадами дослідження трансформаційних процесів на Тернопільщині в 1939-1941рр. виступають основні концепції національної історичної науки, серед яких важлива роль належить положенню про єдність і взаємозв'язок явищ та процесів всесвітньої, вітчизняної й регіональної історії, що вимагало осмислення акту окупації Західної України радянськими військами й наступної анексії західноукраїнських земель з їх включенням до складу СРСР у контексті подій і міждержавних відносин на першому етапі Другої світової війни.

Принципове значення має концепція безперервності історичного процесу, за якою кожне суспільне явище $є$ наслідком попереднього та причиною наступного й застосування якої дало змогу 
аргументовано розкрити алгоритм імперської політики Кремля що була спрямована проти національного чинника.

За потреби враховувалася концептуальна теза про пріоритетне значення національної ідеї та національного державотворення як стратегічної мети суспільно-історичного поступу народу. Студентам важливо пояснити що саме національна ідея спроможна згуртовувати всі верстви та ресурси в боротьбі за суспільно-політичні і та соціально-економічні права народу. Про це переконливо свідчить історія наших днів.

Саме в цю площину було спрямоване вістря комуністичної пропаганди та практичні заходи репресивних органів із чітко визначеним комуністичною партією завданням: знищити прагнення національно свідомих громадян до самостійної держави ще на етапі національної ідеї.

Наявність супротиву місцевого населення заходам насильницької радянізації підтверджувала такі прагнення, а масові репресії партійно-державної влади проти місцевого населення виступали і як форма реакції на національний опір, і як засіб здійснення трансформаційних процесів соціалістичної спрямованості.

\section{II Матеріали і методи дослідження}

Результативний ефект дало застосування тези про об'єктивний характер історичного процесу: саме об'єктивність суспільних явищ і подій, їх обумовленість комплексом обставин і закономірностей уможливили доведення неспроможності й приреченості соціалістичних трансформацій на Західній Україні як таких, що суперечили історичній необхідності, традиційному, віками сформованому характеру розвитку суспільно-політичної, соціально-економічної та культурно-духовної ссеер і стилю життєдіяльності західноукраїнської спільноти.

У вивченні радянської тоталітарної системи передбачено, що концепт національної ідентичності, застосований до аналізу суспільно-історичних процесів на західноукраїнських землях, відіграє свою теоретико-герменевтичну роль за умови врахування специфіки політичних, господарських і культурних традицій регіону, зокрема громади як джерела місцевого народовладдя, недоторканості інституту приватної власності, насамперед земельної, непорушності авторитету культурно-духовних інституцій, особливо церкви, загальновизнаних об'єктів історичної пам'яті та вікових місцевих, в тому числі родинних, традицій.

У подальшому розкритті матеріалу застосовані системний, комплексний, міждисциплінарний, синергетичний та інші наукові підходи до висвітлення стосунків місцевого населення західного регіону 3 радянською владою у передвоєнний період.

Системний підхід полягає у вивченні трансформаційних процесів в Західній Україні і на Тернопільщині як цілісної системи командно-адміністративних заходів, здійснюваних партійними, державними, господарськими, соціально-культурними та силовими структурами, що діяли функціонально відособлено, проте були інтегровані в єдине ціле спільною стратегічною метою включення краю в радянську політичну систему та формування в ньому соціалістичних економічних відносин і насадження комуністичної ідеології як єдиного світогляду громадян.

Пріоритет у такій системі належав партійним органам як її керівному ядру, бо здійснювані ним заходи виступали зв'язуючим елементом діяльності всіх її структур, а прийняті рішення - імпульсом до виконання завдань радянізації суспільного життя.

Однак місцеве партійне ядро не володіло функціональною автономією, а підпорядковувалося вищим керівним органам за принципом авторитарної ієрархії, сформованої партійно-державною бюрократією: ЦК - обком - райком (міськком) - первинна парторганізація. Отже, системний підхід дозволив розкрити механізм і структуру партійного управління соціалістичними трансформаційними процесами в регіоні.

Комплексний науковий підхід полягає у вивченні об'єкта дослідження в сукупності його властивостей, характеристик, структурних елементів, які мають загальне призначення.

У поданому матеріалі таким об'єктом виступає західноукраїнське суспільство, а предметом вивчення - трансформаційні процеси в усіх його структурно-функціональних складових, настільки взаємопов'язаних, що трансформаційні зміни в одному з них викликають функціональні зрушення в інших, а в кінцевому підсумку - в усій структурі. Зокрема, націоналізація майна, здійснена у секторі 
приватної власності, спричинила кардинальні зміни у сферах виробництва, обслуговування, охорони здоров'я, освіти й культури, а головне - уможливила формування командно-адміністративної системи управління.

Отже, комплексний підхід до аналізу трансформаційних процесів дав змогу визначити, що серед сукупності радянізаційних заходів пріоритет належить ліквідації інституту приватної власності як економічної основи демократичних свобод і здійснення націоналізації засобів виробництва й об'єктів виробничої та невиробничої інфраструктури для утвердження державної власності як економічного фундаменту тоталітарного радянського устрою.

Важливе значення для результативного й всебічного висвітлення проблематики має міждисциплінарний науковий підхід, бо трансформаційні процеси в регіоні стосувалися різних сфрер суспільного життя: виробничої й соціально-культурної, державної й громадської, ідеологічної та військової, фрінансової й природоохоронної. Це вимагало застосування понятійного апарату й аналітичного інструментарію економічних, політичних, юридичних і комплексу гуманітарних наук (історії, філософрії, психології, етнографії тощо) та природничо-математичних дисциплін (від агрономії до математики) для фахового висвітлення проблем аграрного виробництва чи здійснення аналізу статистичних даних щодо трансфрормаційних змін у виробничому чи соціально-гуманітарному секторах життя краю.

Застосування інноваційного синергетичного підходу в аналізі здійснення та результативності суспільно-політичних, економічних і соціально-культурних наслідків радянізації регіону дозволило продемонструвати, що трансформаційні заходи, ініційовані імперським центром і впроваджені місцевим партійно-державними органами, породжували та поглиблювали суперечності між об'єктивними закономірностями розвитку краю, суттєвими потребами й прагненнями його населення з одного боку та сукупним феноменом колоніальної політики Кремля в регіоні - 3 іншого.

Формувалися своєрідні «біфуркаційні ножиці» як роздвоєння суспільного життя регіону на сферу інтересів населення й сфреру партійно-державних інтересів. Причому таке роздвоєння поглиблювалося, переростало у протиріччя з кожним новим силовим рішенням центральної чи місцевої влади, а згадані рішення відігравали роль «фрлуктуаційних імпульсів» як раптових, неочікуваних відхилень від традиційних норм суспільного життя.

Нагромадження флуктуацій вело до посилення потенціалу негентропії - негативного ставлення аж до неприйняття й опору населення примусовим заходам влади, насильницьким методам управління. Синергетичний підхід дозволяє відповісти на питання, чому саме на теренах Західної України - першій в СРСР (!) - розпочалася боротьба за відновлення національної державності наприкінці 80-х - початку 90-х рр. минулого століття: комуністичний режим десятиліттями посилював революційний потенціал місцевого населення, котре більше ніж в інших регіонах імперії зберігало національні традиції і некомуністичний уклад суспільного життя.

Аналіз і синтез, як універсальні та взаємопов'язані методи пізнавального процесу й науководослідницької роботи, застосовувалися для абстрактного розчленування об'єкта дослідження на окремі частини для детального вивчення їх сутності, форм і функціональних особливостей з наступним об'єднанням у цілісне утворення з уже відомими взаємозв'язками між його елементами.

Внаслідок цього такі суспільні явища, як трансформаційні процеси й радянізація з "речі в собі“ стали "річчю для нас": аналіз окремих перетворень і змін, здійснених радянською окупаційною владою в різних сорерах суспільного життя, уможливив синтез висвітлених характеристик і ознак у наукові концепти "трансформаційні процеси" і "радянізація". Важливе значення для усвідомлення цілісної картини студентами про запровадження радянських порядків на території Західної України в19391941 pр, є використання під час аудиторної роботи не тільки архівних матеріалів а також публікації авторів діаспори.

В ході захоплення Червоною Армією Тернопільщини розпочалося вирішення земельного питання за радянською методологією. Створювалися селянські комітети, які під керівництвом тимчасових управлінь (а в них абсолютно переважали представники окупаційної влади) брали на облік безземельних і малоземельних селян, а також тих, хто не мав коней, корів, сільгоспреманенту.

У Тернопільському воєводстві за перші два місяці діяльності селянські комітети передали малоземельним і безземельним селянам понад 213 тис. га землі, 10 тис. коней, 8,6 тис. корів, 3,7 тис. 
свиней, значну кількість посівного матеріалу. Вони ж виділяли поміщицькі угіддя під пасовища для селянської худоби, організовували копання цукрових буряків на колишніх поміщицьких плантаціях [1, с. 71-72].

Бажаючи, щоб суспільство було рівноправним у володінні капіталом і продуктами праці, система комунізму аналізує і критикує попередній польський лад і форми соціального життя, вважаючи цей порядок безперспективним, і тому намагається виправити недоліки сформованого соціального побуту західноукраїнського суспільства, утвердити власне право будь-яким способом, надати йому законну силу.

\section{III Результати}

Однак перші кроки радянської влади, нібито спрямовані на ліквідацію соціально-економічної несправедливості та диспропорцій в аграрній сфері регіону, що склалися внаслідок антиукраїнської політики польської адміністрації, бажаних для більшовиків результатів не дали. Незважаючи на заклики керованих більшовиками селянських комітетів щодо розподілу конфіскованих земель, селяни брали їі неохоче, а деякі відмовлялися зовсім. Насамперед супротив обумовлювався споконвічним почуттям приватної власності («не моє!»). Другою причиною було переконання місцевих жителів у недовговічності більшовицького режиму. По-третє, значна частина селян усвідомлювала, що аграрна політика більшовиків, реалізована ними на сході України, не передбачала такого «дару», як земельна власність, а тому пропонований ними розподіл земель сприймався лише як тимчасовий облудний маневр. Хоча про колективізацію села нова влада ще не згадувала, та про неї знали сільські господарі із «східноукраїнського досвіду» і здогадувалися, що таке чекає Західну Україну. Тому до кінця 1939 р. селяни не розібрали навіть половини поміщицьких земель. А всі конфісковані землі не були розібрані й до червня 1941 р. [2, с. 314-315]. . Законодавчу основу конфіскації, націоналізації й передачі селянам поміщицьких земель надала прийнята Народними Зборами Західної України Декларація, що гласила: «На звільненій у поміщиків і капіталістів землі Західної України єдиним законним ії господарем $є$ трудовий народ: робітники, селяни і трудова інтелігенція» [3, с. 312-313]. Згідно з нею, у колишніх землевласників конфісковано 2,5 млн га орної землі, що складало майже 29,5 \% земельних угідь краю. Загальна площа експропрійованих і націоналізованих земель у Західній Україні перевищила 8 млн га, 3 яких безземельному й малоземельному селянству передано 4,5 млн га ріллі, луків і пасовищ. До грудня 1939 р. селянські комітети розподілили між бідняками понад 1,1 млн га землі. Крім того, селяни отримали худобу, сільгоспреманент, зерно. Сільським жителям Тернопільщини передали понад 13 тис. коней, більше 14 тис. корів, 5,5 тис. свиней, 4,4 тис. овець. Загалом у західних областях одержали 84 тис. коней, близько 100 тис. голів BPX, 14 тис. свиней, 27 тис. овець [3, с. 312-313].

Слід зауважити, що перші конкретні кроки радянської влади щодо націоналізації землі, засобів виробництва, робочої худоби, майна були досить обережними та завуальованими. Підтвердження такому підходу знаходимо у перших постановах, створених у повітах тимчасових управлінь, де простежується підступний алгоритм радянської націоналізації. Оголошено про створення селянських комітетів з бідняків і середняків для захоплення й розподілу земель колишніх землевласників. При цьому наголошується, що відібрані землі розподіляються лише між колишніми наймитами, бідняками й середняками, проте із застереженням, що ці землі та все майно колишніх експлуататорів береться на облік і передається під охорону селянських комітетів. Насамкінець попереджається, що винні у розбазарюванні відібраного й облікованого майна притягатимуться до суворої відповідальності [4, с. 4].

Наступне в задумі радянської влади - знищення трудових селянських господарств і перетворення їх власників, споконвічних сільських господарів, у звичайних одержавлених наймитів, які замість прибутку з приватного господарювання отримували мізерну платню від господаря-держави у вигляді трудоднів. Таким способом радянська влада отримувала десятки мільйонів дешевих робочих рук, які можна було планово й примусово використовувати в будь-який час і за будь-яким призначенням.

В загальному, за задумом партійно-державного керівництва, колективізація сільського господарства, позбавляючи селян основних засобів аграрного виробництва (землі, робочої худоби, засобів обробітку землі), була покликана поступово знищити у психології селян почуття приватної власності, а у свідомості - сприйняття себе приватним власником. Тобто ліквідувати економічний 
фундамент індивідуальної свободи сільського трудівника, а з цим і його прагнення до національної свободи й можливості реального супротиву комуністичному деспотизму [5, с. 126-127].

Особливо привабливим для нової окупаційної влади був аграрний потенціал Тернопільської області. Посівні площі Тернопільщини в 1940 р. складали 961,8 тис. га, Посівні площі Тернопільщини були найбільшими серед ново-приєднаних областей: Волинська область - 682,5 тис. га, Рівненська 629,1 тис. га, Львівська - 506,1 тис. га, Станіславська - 460,6 тис. га, Дрогобицька - 399,3 тис. га, Чернівецька - 390,1 тис. га, Закарпатська - 219,1 тис. га. Посівна площа всіх земель західних областей перед їх приєднанням до УРСР складала біля 5,9 млн га. За довоєнною статистикою, посівні площ УРСР за рахунок приєднання Західної України збільшились із 25,6 млн га до 30,2 млн га [6, с. 136-139].

Економічною основою такого переходу радянська влада вважала ті землі й те майно, яке селяни Тернопільщини отримали після ліквідації поміщицького й монастирського землеволодіння (200 тис. га землі, більше 11 тис. коней, понад 11 тис. корів, 1,2 тис. волів, 14,3 тис. центнерів насіння зернобобових культур, 18,5 центнера картоплі, 150 центнерів насіння багаторічних трав) [7, с. 46].

На квітень 1940 р. в області організовано 45 колгоспів, що об'єднували 3905 селянських господарств. Новоствореним колгоспам держава передала 3 тис. житлових і господарських будинків 3 колишніх поміщицьких маєтків, 1570 коней, 3240 голів ВРX, 900 свиней, 1440 овець і надала понад 230000 карбованців кредиту. Радянська пропаганда вважала, що за рахунок такої підтримки покращились основні показники аграрного виробництва краю. На початок 1941 р. в області вже працювали 95 колгоспів, результати господарської діяльності яких були такими: середні врожайність зернових досягла 13,2 ц/га, цукрових буряків - 215 ц/га, картоплі - 139 ц/га [7, с. 48].

Високі темпи соціалістичних перетворень у сільському господарстві області радянські історики ілюструють такими даними: на 1 червня 1941 р. в області діяли 529 колгоспів, які об'єднували 46,5 тис. селянських господарств (15\% всіх сільських господарів області) і яким належали 183,8 тис. га землі (18 \% всіх земельних угідь Тернопільщини) [7, с. 47-49].

Діаметрально протилежну оцінку витоків, причин, характеру здійснення колективізації, стилю, форм і результатів роботи колективізованих господарств дають позабільшовицькі літературні джерела, які підкріплюють свої оцінки вагомими статистичними показниками, недоступними громадянину Країни Рад з причини радянської цензури й змісту комуністичної пропаганди. Доцільно конкретизувати параметри економічного тиску на селян. Одноосібні господарства зобов'язані були «продавати» державі по 20 кг м'яса з кожного гектара землі (при розмірах наділу до 2 га), по 30 кг м'яса (при наділі до 5 га) і по 50 кг (при наділі до 10 га). Держава платила селянинові 6 - 7 коп за 1 кг м'яса при ринковій ціні 75 коп./кг. Таке ж співвідношення складалося і при «продажу» зерна державі: по 90 кг з кожного гектара (обов'язково перед жнивами!), за які держава платила по 60 коп. за 1 кг пшениці (на ринку - 1,8 крб.) і 50 коп за 1 кг жита (на ринку - 1,2 крб.). Влітку 1940 р. із селян почали стягувати ще й грошовий збір: по 50 крб. за 1 га землі, по 60 крб. за 1 корову, по 120 крб. за 1 коня [2, с.317-319]. Комунізм взяв на себе не природню функцію дозувати свободу, прикриваючись правом, навіть рівноправністю. Якщо галицький селянин більше працював і відповідно мав більший дохід по відношенню до того хто менше працював, або зовсім не працював, то відповідно мав би на власний розсуд розпоряджатися своїми достатками. Але комуністична система рішуче блокувала його особисту волю, позбавляючи власних достатків для інтересів новоформуючого комуністичного суспільства і не дозволяла самим селянам розпоряджатись результатом власної праці

Однак, незважаючи на всі зусилля більшовицької влади, колективізація на західноукраїнських землях особливого успіху не мала: серед кількасот організованих колгоспів більшість становили колгоспи-карлики з 10-20 об'єднаними селянськими господарствами. Складалася ситуація, коли на одного колгоспника припадало до 5 га землі, тому не всі землі засівали, а посіяне й посаджене доглядали недбало і збирали невчасно [2, с. 326-327].

Партійно-державна влада вживала різноманітні нормативно-адміністративні заходи для прискорення переходу до соціалістичної системи господарювання в аграрній галузі західноукраїнської економіки. У Тернопільській області селянам-одноосібникам дозволялося мати в користуванні до 7 га сільськогосподарських угідь, а в деяких районах (Вишнівецький, Збаразький, Лановецький, Катербурзький, Новосільський, Почаївський і Шумський) - до 10 га. Усі залишки землі понад встановлені норми у некооперованих селян вилучалися і передавалися колгоспам або в Земельний 
фонд (при відсутності колгоспів) для наділення землею безземельних і малоземельних селян, а згодом і для новоорганізованих колгоспів. Практичне виконання постанови покладалося на сільські ради, яких у цьому питанні контролювали виконкоми районних рад, що діяли під керівництвом райкомів партії [8, с. 43-44].

Усі державні заходи не тільки не враховували інтересів селянина, як основного суб'єкта сільськогосподарського виробництва, а й були спрямовані на подальше його закріпачення, позбавляли найменшої свободи і посилювали державний грабунок його праці, чим знищували будь-які стимули до його зацікавленої участі в сільськогосподарському виробництві. За статистичними даними, доступними на ту пору лише зарубіжним дослідникам, продукція колективізованого сільського господарства СРСР в 30-х роках складала лише 55-58 \% аграрної продукції 1913 р. [5, с. 128-129].

Комунізм в силу принципу рівності між членами суспільства, деспотично забороняв мати будь яку приватну власність. Якщо ця власність в одного мала великі розміри, а в іншого малі, або її зовсім не було, то комунізм негайно її урівноважував. Отже спільне і рівноправне володіння всіма капіталами і продуктами праці - це основна і незмінна вимога системи яка насаджувала її всіма засобами аж до репресій. Тотожні трансформації спостерігаємо і в інші соціально-економічні сфері області. Першим кроком революційно-демократичних перетворень у промисловості було встановлення робітничого контролю над виробництвом з боку спеціально створених робітничих комітетів. Використовуючи високу суспільно-політичну та трудову активність робітників, зазначається у радянських дослідженнях, і спираючись на тимчасові органи народної влади, робітничі комітети організовували збереження майна підприємств, встановлювали 8-годинний робочий день, забезпечували нормальну роботу трудових колективів, здійснювали контроль за виробництвом і рівнем заробітної плати, повертали на робочі місця робітників, звільнених раніше за політичну неблагонадійність.

Лише за січень 1940 р. на Тернопільщині створено 28 артілей. Разом з націоналізацією в економіку регіону прийшли радянські методи господарювання, однією з характерних рис якого було розростання адміністративного апарату: на 4 - 5 працюючих припадав один управлінець, що вело до удорожчання продукції через зростання ії собівартості. Зазнала реформи банківська система: 414 націоналізованих банків і 1500 кредитних установ були об'єднані в 6 обласних контор і 50 районних відділень Держбанку СРСР. Керівництво фінансовими потоками здійснювалося лише з Москви [9, с. 107-108].

Партійно-державні органи краю практично одночасно з прийняттям відповідної постанови ЦК ВКП(б) щодо націоналізації промислових об'єктів розпочали активну кампанію з ліквідації приватної власності у виробничій сфері як головної перешкоди на шляху соціалістичної трансформації всієї системи соціально-економічних відносин і формування всіх структурних елементів соціалістичної економіки в радянському (на ту пору сталінському) варіанті.

Державні органи своїми постановами визначали конкретні списки фабрик, заводів, банків, підприємств транспорту й зв'язку, комунального господарства, побутових установ, а також великих будинковолодінь, які підлягали націоналізації, створили для цього спеціальні комісії, які розпочали процес деприватизації. Націоналізація, що спочатку проводилася на підставі постанов тимчасових управлінь, перейшла у повне відання виконкомів областей і повітів (районів). У зв'язку із цими постановами на підприємствах, в установах і закладах проводилися збори робітників і службовців, де представники органів влади оголошували рішення про націоналізацію об'єкта й про призначення нового керівника. Загалом по Західній Україні націоналізовано 1998 підприємств, з них 251 - в Тернопільській області [1, с. 127-129].

Націоналізація промисловості й банків створила економічні основи для соціалістичної трансформації народного господарства західних областей, а також, як вважають аналітики радянських часів, для ліквідації їх господарської й культурної відсталості та піднесення до рівня передових областей Радянської України. Підкреслюється, що цьому сприяла й допомога з боку російського та інших народів СРСР, які надсилали на Західну Україну промислове обладнання, механізми й техніку, матеріали, необхідні для розвитку всіх галузей промисловості краю. РНК УРСР і ЦК КП(б)У постановою від 16 лютого 1940 р. затвердили план індустріалізації західних областей Української РСР на 1940 р.. Для асигнування такого стратегічного плану РНК СРСР виділив на промисловість краю 2,7 млрд крб. [1, c. 130]. 
Керівництво області виходило з того, що націоналізація промислових об'єктів створює необхідні передумови для перебудови і розвитку різних галузей промисловості. Вже у квітні 1940 р. в області працювали кілька сотень промислових підприємств, де було зайнято понад 10 тисяч робітників. Тільки в Тернополі діяло 36 підприємств, на яких працювали 1480 робітників. На базі дрібних кустарних виробничих об'єктів створено 11 райпромкомбінатів, 4 райхарчкомбінати й 4 торфопідприємства. Після укрупнення дрібних промислових одиниць наприкінці 1940 р. в області діяли:

- 14 підприємств союзного,

- 111 - республіканського,

- 108 - обласного;

- 15 промислових комбінатів районного підпорядкування.

Де працювали більше 10 тисяч робітників. Загальна кількість працюючих у державній і кооперативній промисловості перевищила 16 тис. осіб [10, с. 22-23].

Радянські історичні джерела вказують, що високими темпами розвивалася промисловість області в першій половині 1941 р.: достроково створено майже 20 промкомбінатів, 26 промартілей, декілька комунально-побутових закладів. Підприємства освоїли 41 новий вид виробів з місцевої сировини. Загалом за 1939 - 41 роки в області збудовано й реконструйовано Радянсько-сталінський варіант націоналізації наніс нищівний удар по важливій та ефрективній структурі українського господарського життя, як промислова кооперація, що мала вікові традиції. До вересня 1939 р. особливо важливу роль в господарському житті західноукраїнського населення відігравали саме кооперативи. Розгалужена система кооперативів діяла у Тернопільському воєводстві:

- «Центросоюз» виготовляв мило і нитки,

- «Суспільний промисел» - цикорій і каву,

- «Будучність» - цигаркові папірці та гільзи,

- «Калина» і «Продукція» - мармелад і овочеві консерви,

- «Пласт» - печиво,

- кооперативи в Теребовлі й Рогатині - м'ясні вироби,

- «Фортуна» - цукерки,

- «Елегант» - пасту до взуття тощо.

Під кінець 1938 р. молочний кооператив «Маслосоюз» об'єднував 138 районних молочарень, що мали по селах понад 2000 молокозбірень. У «Молокосоюзі» було скооперовано 41 \% сільських господарств, що давали більше 200 тисяч постачальників молока, які упродовж 1938 р. поставили до молочарень 115 млн літрів молока й виготовили 3,25 млн кг масла. Перша більшовицька окупація Західної України у вересні 1939 р. не припинила розвитку української кооперації - вона її просто ліквідувала» [11, с. 460-461].

\section{IV Обговорення}

Отож, націоналізація західноукраїнської економічної сфери руйнувала налагоджені у попередні часи зв'язки й знищувала традиційні форми українського господарського життя. Загалом процес перебудови економічного життя західноукраїнських земель здійснювався на випробуваних в СРСР принципах, але був максимально стиснутим у термінах виконання завдань кожного з їі етапів. Тому насамперед здійснювалося формування основи більшовицької системи господарства - державної власності через націоналізацію промисловості, торгівлі, банків та землі й сільськогосподарських об'єктів, а загалом - через ліквідацію приватної власності. Приватного власника, як капіталістаексплуататора, як джерело контрреволюційної пропаганди, влада знищувала економічно або навіть фізично. Цього, вважали більшовики, заслуговував і купець-спекулянт, який не лише жив за рахунок комерційного обману трудящих, а й деморалізував суспільство. Третьою ворожою категорією, проти якої спрямовувалися заходи приватизації, були заможні сільські господарі, в радянській термінології «куркулі», діяльність яких вимагала посиленої уваги органів НКВС. Саме тому до керівництва господарськими структурами різних рівнів і профрілів залучалися не досвідчені господарники, не кваліфіковані працівники, а ті, хто не мав приватної власності, об'єктів господарювання, а отже, і не мав досвіду господарської діяльності, зате не був скомпрометованим буржуазновласницьким минулим [2, с. 258-259]. 
Водночас із руйнуванням традиційних і підтверджених часом есрективних форм і принципів економічної діяльності господарських структур Західної України партійно-державний центр нав'язував штучні антидемократичні та неприйнятні для регіону форми й методи організації господарського життя. Армія апаратників, що сиділа в наркоматах Москви й Києва, засипала господарські установи Західної України тисячами безглуздих директив, інструкцій і вказівок, яких фахівці на місцях не встигали навіть прочитати. Виробництво, розподіл і постачання на місця виготовленої продукції за документами виглядали продумано й узгоджено, але на практиці панувало повне безладдя: товари, необхідні влітку, поставляли взимку; для ближчих до центру місцевостей була характерна затовареність, а у віддалених населених пунктах панував гострий десіцит цих же товарів; [2, с. 262-264].

Відповідно до вкрай громіздкої дилетантської та вищою мірою неефективної системи управління виробничою сферою була запроваджена система фальшивого соціалістичного обліку у формі так званої радянської статистики, для якої об'єктивність даних не була обов'язковою умовою звітності. Більшовицька статистика віддавала перевагу зіставленню відсотків, а не порівнянню фактичних економічних показників.

Для ілюстрації: невелика соціалістична взуттєва фрабрика, що випускала на рік 2 тис. пар взуття, після розширення виробничих площ і збільшення кількості працюючих стала випускати по 4 тис. пар взуття, тобто ріст виробництва склав 200 \% при фрактичному збільшенні продукції на 2 тис. одиниць; велика капіталістична взуттєва фабрика, яка виробляла щорічно по 20 тис. пар взуття, збільшила виробництво на 4 тис. пар, що дало приріст випуску продукції на $20 \%$. В результаті, за більшовицькою статистичною методикою, соціалістичне підприємство працює в 10 раз ефективніше від капіталістичного (зростання на $200 \%$ проти 20 \%), хоча реально приріст капіталістичного виробництва в натуральних вимірах був удвічі більшим (4 тис. пар проти 2 тис. пар). "Хитрість» більшовицької статистичної методики полягала у свідомому ігноруванні або замовчуванні вихідної бази статистичних підрахунків [5, c. 67-68].

Бюро обкому КП(б)У вважало націоналізацію «глибоко політичною справою», вирішення якої не зуміли забезпечити голови міськрад і райвиконкомів та секретарі повітових і міських комітетів партії. Персонально вказано заступнику голови облвиконкому та завідуючому облкомунгоспом «на відсутність з їх боку належного керівництва ходом націоналізації в області». Цим визнано, що націоналізація здійснювалася державними структурами краю під керівництвом партійних органів.

Бюро обкому вирішило здійснити перевірку рівня організації роботи націоналізованих підприємств, створити інститут керуючих будинками (кербудів) і провести з ними відповідну нараду, а також на одному з наступних засідань заслухати звіт облвиконкому та облкомунгоспу про підсумки націоналізації підприємств в області. На бюро було оприлюднено факти зловживання службовим положенням при націоналізації майна: начальник облвідділу зв'язку незаконно провів націоналізацію приміщень для потреб працівників апарату цього відділу [12, арк. 6].

Згаданий факт не був поодиноким, бо порушення встановлених норм і правил стали невід'ємною ознакою бюрократичної системи управління, що підпорядковувалася лише партійним вказівкам i зневажала нормативні приписи й вимоги, перекладаючи їх на плечі підлеглих. В умовах такої системи справа націоналізації загрожувала вийти з-під контролю, бо у процесі її здійснення відкривалися широкі можливості управлінському, в тому числі й партійно-бюрократичному, апарату для зловживань в особистих інтересах. Під націоналізацію незаконно потрапляли лікарі, вчителі, інженери, навіть робітники й квартиронаймачі, водночас приватні власники, зокрема власники великих будинковолодінь, залишалися поза націоналізацією. Однак порушення та зловживання при проведенні націоналізації продовжувалися, про що свідчать багаточисельні заяви мешканців Тернополя до президії міської ради зі скаргами на несправедливу націоналізацію їх майна. Зокрема, на засіданні президії Тернопільської міськради 19 березня 1940 р. таких заяв розглядалося більше двадцяти. Рішення приймалися практично однотипні: після аргументації «у зв'язку з тим, що...» йшов конкретний висновок, за яким слідувало: «націоналізацію вважати правильною і в проханні відмовити» [13, арк. 86-87].

Практичний аспект націоналізації майна в області неодноразово вивчався Тернопільським облвиконкомом. Так, на засіданні президії облвиконкому 25 січня 1940 р. слухали питання «Про націоналізацію, облік і збереження державних фондів у Борщівському повіті». У постанові зафіксовано низку грубих порушень. Насамперед, у повіті націоналізували 20 дво- три-кімнатних будинків, що явно 
не підлягають націоналізації, а їх власники не належать до категорії заможних громадян (приватних власників). Причому одночасно у власників повітвиконком «відібрав особисте майно, навіть не залишивши необхідної кількості харчових продуктів і предметів першої необхідності». Мешканців незаконно націоналізованих будинків виселяли на вулицю, не пропонуючи взамін інших житлових приміщень. Націоналізоване майно свідомо обліковувалося недбало, що створювало умови для його розкрадання. Водночас мали місце випадки повернення націоналізованих будинків і майна крупним власникам без будь-яких на це законних підстав [14, арк. 6-7].

Окремі негативні прояви процесу націоналізації були настільки тривожними й резонансними, що 3 метою уникнення радикальної реакції місцевого населення партійні органи вдавалися до жорстких персональних рішень. Так, за спробу націоналізації та опису майна ченців монастиря с. Михайлівка Борщівського району завідувача відділу Борщівського повіткому КП(б)У звільнено з посади, розпочато слідчі дії, а питання про його партійність вирішувалося після завершення слідства [15, арк. 24].

3 метою запобігання помилкам і порушенням у процесі націоналізації в міськрадах і повітвиконкомах затверджували списки об'єктів, що підлягають націоналізації з детальною їх характеристикою. Один із таких списків затвердила президія Тернопільської міської ради 13 січня 1940 р. Рішення по кожному об'єкту зі списку формулювалося стандартно: «Будинок гр. Енгля, вул. Коперніка, 9, що складається із 10 квартир, 31 кімнати, має житлову площу 582 кв. м., та його майно націоналізувати, а мешканців із квартир переселити» [16, арк. 155].

\section{V Висновки}

Таким чином процес націоналізації в області проходив настільки складно і суперечливо, що у звітній доповіді на І-й звітній обласній партійній конференції у квітні 1940 р. повідомлено лише про певні успіхи в націоналізації поміщицьких і монастирських земель, а щодо націоналізації у сфері промислового виробництва та будинковолодіння делегатів конференції поінформовано про «численні порушення соціалістичної законності». Оприлюднено також фракти супротиву місцевих жителів. Наприклад, жителі села Михайлівка Борщівського району побили членів волосного комітету за спробу націоналізувати майно місцевого монастиря. Обурення населення викликали факти привласнення чиновниками, в основному працівниками місцевих виконкомів, націоналізованого майна. Такому привласненню у формі розкрадання сприяла недосконала процедура націоналізації: здебільшого без опису майна, без належного оформлення актів та іншої документації. У підсумку, визнається у звітній доповіді конференції, обком партії більше займався виправленням системних порушень в ході націоналізації, аніж питаннями їі організації, здійснення та ефективного використання націоналізованого майна» [17, арк. 58-59].

Отже, з вище наведених фактів ми бачимо як відбувалося порушення свободи людини і її права, яка вправі розпоряджатись своєю власністю: чи віддати її громаді, приватній особі, чи користуватись нею самому, не розділяючи її ні з ким. Нажитий нею капітал, звичайно, вільно передає у спадок сину, родичу і т.д. а той отримавши чужу власність шляхом доброї чиєїсь волі, тому має право користуватись нею як завгодно, так як в силу подарка, вона з чужої власності стала його.

Але комунізм не дає права людині розпоряджатись продуктами своєї справи, так як хочеться, а заставляє віддавати у розпорядження іншим. Таким чином комунізм проголошує право в ім'я свободи, віднімає у людини одне із самих суттєвих і невід'ємних його прав - це його волю. Підтвердженням нашої позиції $€$ тлумачення природи комунізму у енциклопедичних словниках дожовтневого перевороту. Комунізм - економічне і соціальне вчення,що вимагає спільності власності і соціальної рівності між особами [18, с.1729].

Комунізм - соціальне вчення, яке намагається зрівняти всіх членів суспільства у власності, шляхом знищення індивідуальної власності і на заміну її пропонується загальна власність, ліквідовуючи приватну власність, інші (комуністи) рекомендують знищити сім'ю і обов'язковість спільних квартир та обідів [19, с. 1028 ]. Комунізм - це плід людського розуму, який заперечував приватну власність. А прагнення до приватної власності $є$ вроджена необхідність всього органічного світу.

Прагнення до власності, в загальному розумінні, у рослинному світі виражаються у всмоктуванні із землі необхідних поживних речовин, в житті тварини це прагнення володіти їжею Людина з малечку, починаючи від іграшки прагне мати щось своє 
В подальшому житті людини це прагнення виражається до забезпечення і володіння всіма засобами для власного розвитку. Власність-вроджена необхідність всього живого,а вимоги комунізму- $\epsilon$ не природніми, а відповідно не реальні в практичному житті.

\section{Бібліографічні посилання}

1. Бабій Б. М. Возз'єднання Західної України з Українською РСР. Київ : Вид-во АН УРСР, 1959. 193 с.

2. Західня Україна під большевиками. IX.1939 - VI.1941 // Збірник статей / за ред. Мілени Рудницької. Нью-Йорк, 1958. 494 с.

3. Возз'єднання західноукраїнських земель з Радянською Україною / за заг. ред. Сливки Ю. Ю. Київ: Наукова думка, 1989. $482 \mathrm{c}$.

4. Як жили робітники,шевці за польського панування. с. 2. / Сталінським шляхом. 1939. 30 вересня (№ 3).

5. Двадцятий з"їзд КПРС без маски / Видання закордонних частин ОУН, 1956. 168 с.

6. Брыль М. Освобожденная Западная Украина. Москва, 1940. 30 с.

7. Історія міст і сіл УРСР [у 26 тт.] Т. ХІХ : Тернопільська область / гол. редкол. Нечай С.П. Київ : Інститут історії АН УРСР, 1973. $640 \mathrm{C}$.

8. 3 історії колективізації сільського господарства західних областей Української РСР // Збірник документів і матеріалів / за ред. Івасюта М. К. Київ : Наукова думка, 1976. 509 с.

9. Ярош Б. О. Тоталітарний режим на західноукраїнських землях. 30-ті-50-ті pp. XX століття (історико-політологічний аспект). Луцьк : Надстир'я, 1995. 175 с.

10. Нариси з історії Тернопільської обласної партійної організації. Львів : Каменяр, 1980. 288 с.

11. Збаражчина. Збірник статей, матеріялів і споминів / за ред. Володимира Жили. Т.1. Нью-Йорк-Париж-Сідней-Торонто, 1980. 740 c.

12. Державний Архів Тернопільської Області ,далі( ДАТО). Ф. П-1. Оп. 1. Спр. 5. Постанова бюро Тарнопольського обкому КП(б)У від 3 січня 1940 року «Про хід націоналізації промислових підприємств і житлових будинків по м. Тарнополю». Арк. 6-7.

13. ДАТО. Ф. Р-9. Оп. 1. Спр. 105. Постанова президії Тарнопольської міської ради від 19 березня 1940 року «Розгляд заяв про невірну націоналізацію майна». Арк. 86-87.

14. ДАТО. Ф. Р-1833. Оп. 6. Спр. 6. Постанова Тарнопольського облвиконкому від 25 січня 1940 року «Про націоналізацію, облік і збереження державних фондів по Борщівському повіту». Арк. 6-7.

15. ДАТО. Ф. П-1. Оп. 1. Спр. 5. Постанова бюро Тарнопольського обкому КП(б)У від 13 січня 1940 року «Про факти описування майна монахів с. Михайлівка Борщівського району». Арк. 24.

16. ДАТО. Ф. Р-9. Оп. 1. Спр. 105. Постанова президії Тарнопольської міської ради від 13 січня 1940 року «Про затвердження списків будинків, які належать до націоналізації». Арк. 154-156.

17. ДАТО. Ф. П.-1. Оп. 1. Спр. З. Стенограма першої обласної партійної конфреренції 23-25 квітня 1940 р. Арк. 1-159.

18. Филиппов . М.М .Енцыклопедический словарь в трьох томах. том II . СПБ .1901г. 2688 с .

19. Павленков Ф. Енцыклопедический словарь . С. Петербург. 1913г. 3104 с.

\section{References}

1. Babiy, B. M. (1959). Reunification of western Ukraine with the Ukrainian SSR. Kyiv: View-AN URSR, 193 p.

2. Rudnytska, Mileny (Ed.) (1958). Western Ukraine under the Bolshovykami. IX. 1939 - VI. 1941. Journal of articles/by New York, $494 \mathrm{p}$.

3. Slivko, I. (Ed.) (1989). Reunification of Western lands with Soviet Ukraine. Naukova Dumka, Kyiv, $482 \mathrm{p.}$

4. (1939 September 30) How to live workers, Shevttsi for Polish domination. P. 2. Stalin's way. (No. 3).

5. (1956). The twentieth Congress of the CPSU without a mask. Publication of foreign Parts OUN, $168 \mathrm{p}$.

6. Bryl, M. (1940). Osvozhdennaya Zapadnaya Ukraine. Moscow, 30 p.

7. (1973). History of cities and villages of the USSR [in 26 TT.] t. XIX: Ternopilska Oblast/goal. The Redcount. Nechai S. P. Kyiv: Institute of History AN URSR, $640 \mathrm{p}$.

8. Ivasyuk, M. K. (Ed.) (1976). From the history collectivization agriculture of western regions Ukrainian SSR//collection of documents and materials. Naukova Dumka, Kyiv, 509 p.

9. Yarosh, B. O. (1995). Totalitarian regime at Western. 30th - 50s 20TH century (historical-political-logical aspect). Nadvirna, Lutsk, $175 p$.

10. (1980). Essays on the history of Ternopil regional party organization. Kamenyar, Lviv, $288 \mathrm{c}$.

11. Zbarazh, (1980). A collection of articles, materials and sporadic/by Ed. Vladimir lived. T. 1. NEW YORK-Paris-Sydney-Toronto, $740 \mathrm{p}$.

12. State Archive of Ternopil Region, further (DATA). F. P-1. Op. 1. Спр. 5. Decree of the Tarnopolish Committee of the State ENTERPRISE (b) of January 3, 1940 "on the process of nationalization of industrial enterprises and residential buildings in the city of Tarnofield". Arc. $6-7$.

13. DATO. F. R-9. Op. 1. Cпр. 105. Resolution of the Presidium of the Tarinopol City Council dated March 19, 1940 "Consideration of applications on the incorrect nationalization of property". Arc. 86 - 87.

14. DATO. F. R-1833. Op. 6. Спр. 6. The decision of the Tarnopolish Regional Executive Committee of January 25, 1940 "on nationalization, accounting and preservation of public funds on Borshchiv County". Arc. $6-7$. 
15. DATO. F. P-1. Op. 1. Спр. 5. Decree of the Tarnopolish Committee on (b) in January 13, 1940 "On the Facts of survey of property of monks S. Mykhaylivka, Borschevsky area". Arc. 24.

16. DATO. F. R-9. Op. 1. Спр. 105. Resolution of the Presidium of the Tarnopolish City Council dated 13 January 1940 "on approving the lists of houses belonging to the nationalization". Arc. $154-156$.

17. DATO. F. P.-1. Op. 1. Спр. 3. Transcript of the first regional party conference on $23-25$ April 1940 Arc. $1-159$.

18. Filippov. M. M. (1901). Entzklopedychesky Slovar in three volumes. volume II. ST. PETERSBURG. G. 2688 p.

19. Pavlenkov, F. (1913). Entzclopedychesky slovarb. S. Peterburg. G. 3104 p.

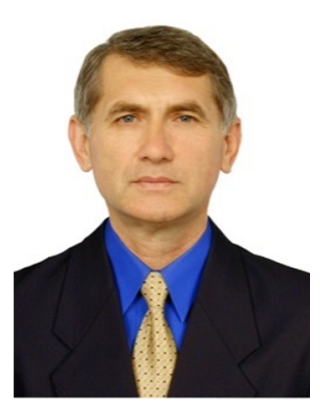

Кравчук Леонід Васильович.

Доктор історичних наук, доцент кафедри педагогіки вищої школи та суспільних дисциплін Тернопільський національний медичний університет ім. І. Я. Горбачевського.

вул. Березова 11/31, м. Тернопіль, Україна

Тел. 0985597507. E-mail: kravchuklv@tdmu.edu.ua

Kravchuk Leonid Vasylovych.

Doctor of Historical Sciences, Associate Professor of the Department of Pedagogy of the Higher School

and Social Sciences,

I.Ya. Horbachevsky Ternopil National Medical University,

Vul. Berezova, 11/31, Ternopil, Ukraine.

Phone: 0985597507. E-mail: kravchuklv@tdmu.edu.ua

ORCID: https://orcid.org/0000-0002-0805-6709

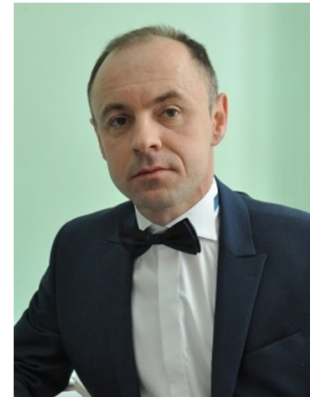

\section{Кадобний Тарас Богданович.}

Кандидат філософських наук, доцент кафедри педагогіки вищої школи та суспільних дисциплін Тернопільського національного медичного університету ім. І. Я. Горбачевського.

вул. Березова 11/31, м. Тернопіль, Україна

E-mail: kravchuklv@tdmu.edu.ua

\section{Kadobnyi Taras Bohdanovych.}

Candidate of Philosophy Sciences, Associate Professor of the Department of Pedagogy of the Higher

School and Social Sciences,

I.Ya. Horbachevsky Ternopil National Medical University,

Vul. Berezova, 11/31, Ternopil, Ukraine.

E-mail: kadobnyj@tdmu.edu.ua

ORCID: https://orcid.org/0000-0002-9150-2051

Кравчук Л. 0.

E-mail: kravchuklv@tdmu.edu.ua

Kravchuk L. 0.

E-mail: kravchuklv@tdmu.edu.ua

\section{Citation (APA):}

Kravchuk L. V., Kadobnyi T. B., Kravchuk L. O. (2020). Formation of democratic values and competence among medical students at the ambushes of the interdisciplinary integration (Sovietization history of Ternopil region in the 1940s). Engineering and Educational Technologies, 8 (4), 26-38. doi: https://doi.org/10.30929/2307-9770.2020.08.04.03

\section{Цитування (ДСТУ 8302:2015):}

Кравчук Л. В., Кадобний Т. Б., Кравчук Л. О. Формування демократичних цінностей та компетентності у студентів-медиків на засадах міждисциплінарної інтеграції ( історії радянізації Тернопільщини в 40-х роках) / Інженерні та освітні технології. 2020. T. 8. № 4. C. 26-38. doi: https://doi.org/10.30929/2307-9770.2020.08.04.03

Обсяг статmі: $\quad$ сторінок-13; умовних друк. аркушів - 1,883. 